\title{
MALBORK (MARIENBURG) CASTLE
}

Kościót Najświętszej Marii Panny na Zamku Wysokim w Malborku. Dzieje, wystrój, konserwacja [Church of the Blessed Virgin Mary in Malbork High Castle. History, Furnishings and Decorations, Conservation], eds. Hochleitner, Janusz - Mierzwiński, Mariusz, Malbork: Muzeum Zamkowe w Malborku, 2016

Kaplica św. Anny na Zamku Wysokim w Malborku. Dzieje, wystrój, konserwacja [Chapel of St Anne in Malbork High Castle. History, Furnishings and Decorations, Conservation], eds. Hochleitner, Janusz - Mierzwiński, Mariusz, Malbork: Muzeum Zamkowe w Malborku, 2016

Wieża Klesza i Domek Zwonnika na Zamku Wysokim w Malborku [Priests' Tower and Bell-Ringer's Cabin in Malbork High Castle], eds. Hochleitner, Janusz - Mierzwiński, Mariusz, Malbork:

Muzeum Zamkowe w Malborku, 2016

Malbork (Marienburg at the time of its construction and its heyday) was the most prestigious castle of the Order of the Teutonic Knights and the seat of the Grand Master of the Order from 1309. Its size is extraordinary as one of the largest castles in the Middle Ages: owing to the slightly elongated shape its length approaches $700 \mathrm{~m}$. This magnitude also comes from the layout of the castle complex: the original so-called High Castle was later added a more ornate Middle Castle to satisfy the special requirements of the central administration of a knightly state, and an

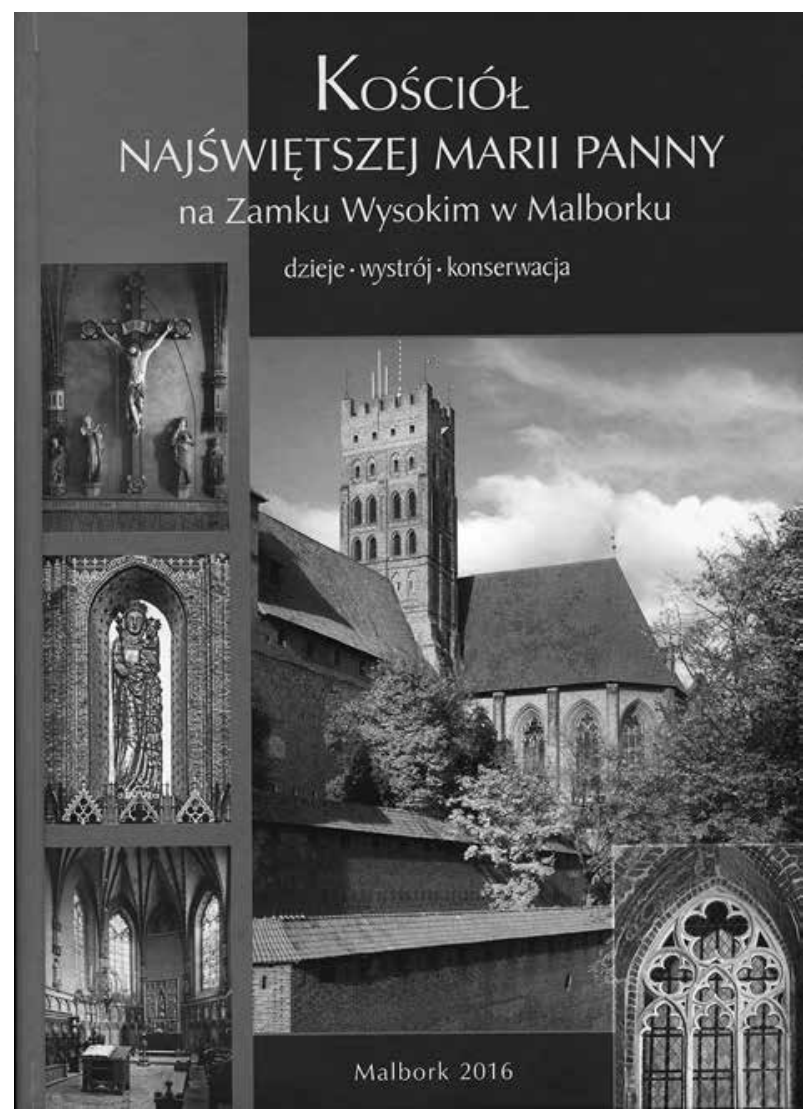

outer section, the Low Castle which mainly served the economic needs of upkeep, so it is the simplest. The building material is brick fried reddish brown - it is justly called the most significant creation of North German Backsteingotik - with ample use of granite in salient places. The strictly rectangular plan of the courtyards of the High and Middle Castles fits this material harmoniously. All this, together with the storied chapel expressing the representative ambitions of the Grand Masters acting as sovereign rulers, the elegant stellar vaults adorning the main

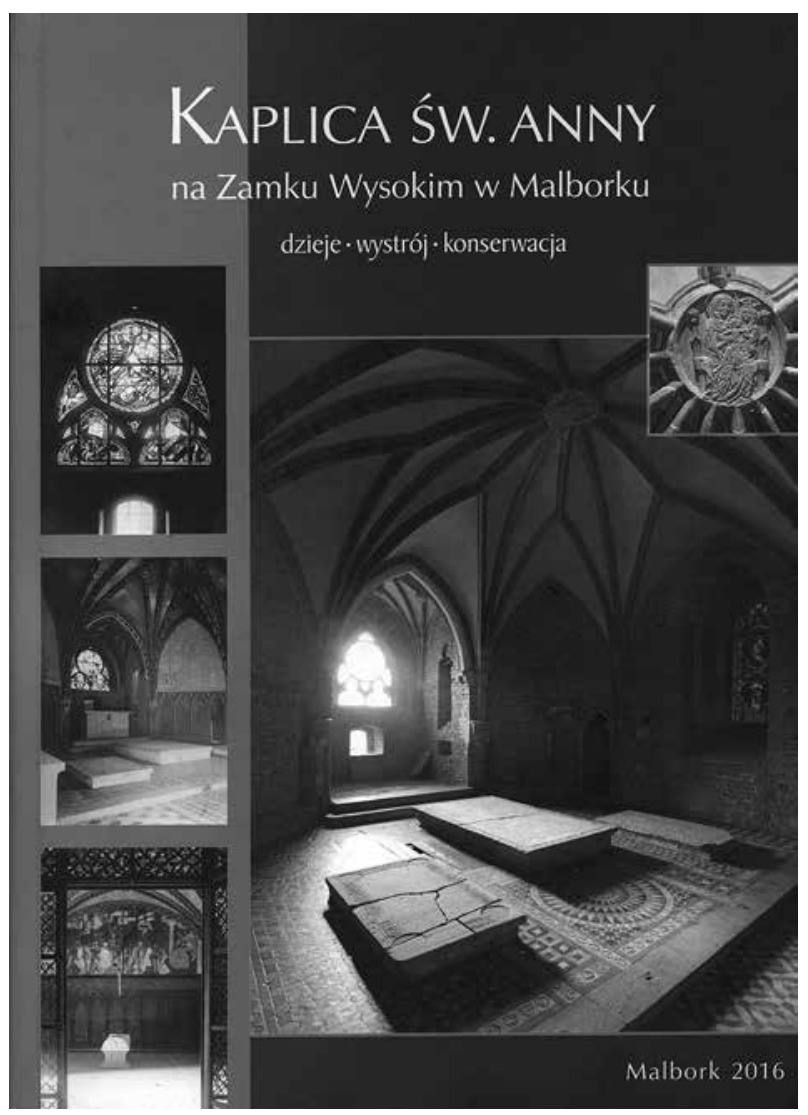




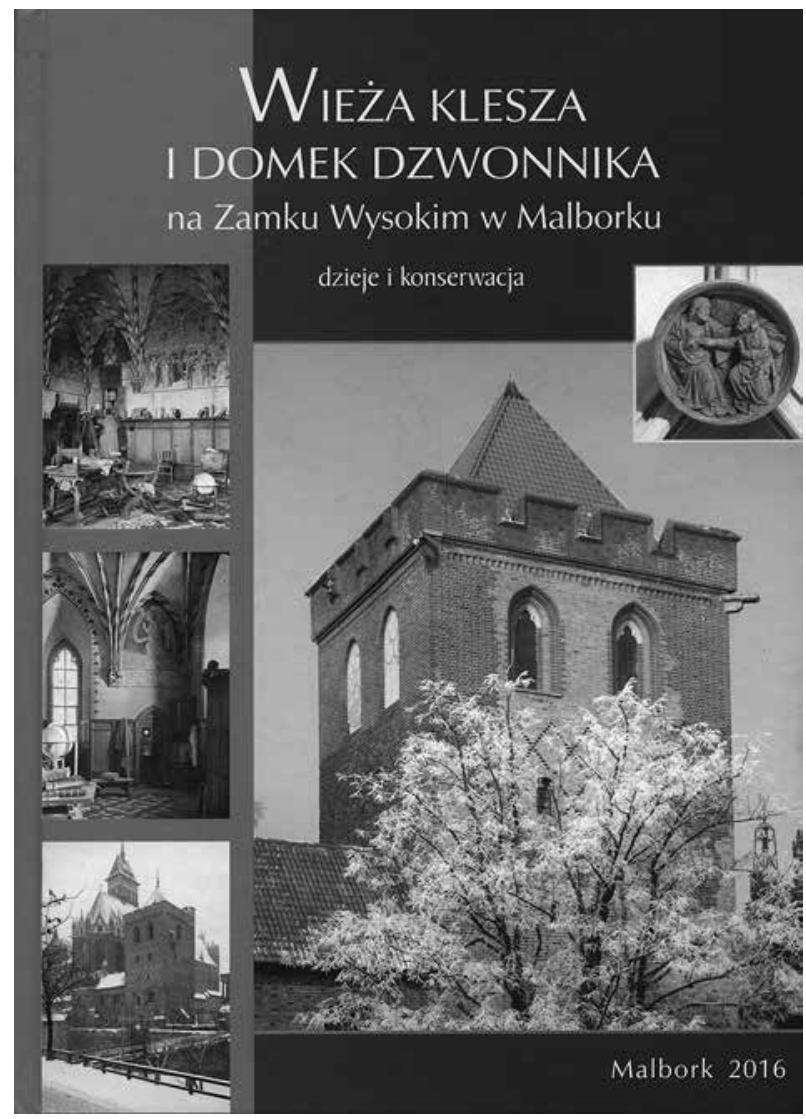

rooms, the powerful overall sight and the originality and subtlety of several details deserve the attention of architecture historians. (Polish researchers consistently call the castle chapel 'church.' The reviewer prefers the general European terminology and uses the term 'chapel' for a place of worship built in a fortress, castle, etc.). In spite of all that, earlier - let us say, pre-World War II - research devoted less attention to Malbork than it deserved. This is particularly conspicuous in the light of the meticulousness with which the reviewed three-tome publication explores a small part - and not the whole - of the castle.

The three volumes of a total of 36 studies were published by the museum housed in the castle. It is the caretaker of the large complex, contributor to the restorations, keeper of the documentation of the history of the Order and of the still ongoing restoration, collector of locally unearthed objects or those with relevance to the place but found somewhere else, organizer of conferences and publisher of diverse informative material. The books at issue crown all former, often highly important publications of historical or architecture historical research. The size, wealth of illustrations and diversity of the scholarly viewpoints bolster the effort to satisfy the expectations aroused by the extraordinary significance of the castle complex. It is to be added that the restoring endeavours required after the grave wartime devastations but meaning to make the most out of necessity have raised lots of theoretical and practical questions of monument conservation, touched on in nearly every paper. The studies inform the reader of the process of restoration, the interruptions for shortage of finances or re-organization, of occasional corrections required by botched work.

The three volumes - it must be reiterated - only present a small but highly important segment of the extensive complex, the north-eastern corner of the High Castle, the salient role of which in the whole of the ensemble is accentuated by the conspicuous protrusion of the Chapel of the Virgin and the undercroft from the rectangular plan of the High Castle. The Priests' Tower next to the chapel is also discussed in the books. The primary aim was to give a highly detailed account of these building sections, to explore the date of their construction, their stylistic contacts, to trace as much as possible the changes in function, reconstructions, furnishing. The writers made good use of the possibilities that arose through restoration, an extremely meticulous process. From the mass of hundreds of cubic metres of rubble the carved stone fragments of vault ribs and cornices, even mosaic tesserae were carefully selected, while the scaffoldings needed by renovation made details on and in the walls tangible in a literal sense. This was complemented by the use of an impressive amount of written documentation about the castle: already in the later phase of the Middle Ages there were lots of mentions of the place, which multiplied in the seventeenth-eighteenth centuries only to become chaotically numerous from the nineteenth century, from which one can only pick some. In addition to the correspondence with the cultural ministry in Berlin about the restoration of the listed monument, the price tenders and invoices of the building contractors and even of individual artisans ready to perform minor jobs are also available, which make the dating of each intervention highly accurate. With the help of the locations of the acquisitions, the orientation of the clients can be outlined. Future Polish or foreign researchers will be deeply indebted to the eliminators of the ruins and to the authors of the three books who summarized their results and added to them their own conclusions.

The main dilemma of post-World War II restorations was whether the medieval state was to be explored by all means, or the German reconstructions 
of the more recent past were to be followed. The latter option entailed further challenges: was the early nineteenth-century creation of romantic architects stylizing the medieval castle, then a tumbledown military depot, into one of the magnificent monuments of the Prussian past to be adopted, or should they align themselves with what the German monument conservationists well advanced in scientific knowledge and competence completed at the end of the same century, when the prime mover of the work was Conrad Steinbrecht? Eventually several solutions can be found, for even if authenticity was the leading concern, the problem remained: the product of which age was to be reconstructed, knowing that every solution would be contestable. Every decision of the recent past was thrashed out thoroughly, as can be read at several loci in the three books.

Most often the conditions prior to the devastations of the world war were decided upon, but, for instance, the ceramic tiles of the chapel floor were replaced by large flagstones in keeping with old representations this time they gave priority to the late medieval solution instead of Steinbrecht's. The walls of the chapel were not plastered again as a memento of the destructions of the war. Although in St Anne Chapel the frescoes painted by a certain Hermann Schaper in 1911 were redone, they are in grisaille, instead of the original colours. The two buildings that are not medieval in their present form but erected a hundred and twenty years ago - the Priests' Tower and the Bell Ringer's Cabin were accurately renovated. It was also raised that the chapel of the Virgin and St Anne Chapel should be left in a state of ruin and a digital image restitution of its former excellence should be prepared with the help of laser and computer technologies. After the war, seething hatred against the Germans even suggested that the castle stylized by the Nazis into a relic of German glory should be pulled down to the last brick.

Generally speaking, in the second half of the nineteenth century - in which the most influential role was played by Steinbrecht, who also carried out analyses of wall texture and excavations to find an early state when the examination of architectural elements in the castle did not provide unambiguous clues for reconstruction, possible solutions were sought among the buildings of the vicinity or their furnishings. Such details are meant as the battlement of the highest tower of the castle which was modelled on the belfry of the episcopal cathedral of Kwidzyn (Marienwerden), the replacement of the missing medieval glazing of stained glass which was partly solved by removing some windows from the churches of Torun (Thorn) and Chełmno (Kulm) and having some others produced in fitting style. People in the nineteenth century did not find such combinations objectionable at all. When seemingly medieval liturgical objects or pieces of furniture were needed for the church or some empty room, the mentality of the age required new ones to be made "in style," choosing models from North German areas and sometimes from Cologne. For example, the newly built high altar of the Chapel of the Virgin was painted after a Cologne model because the incumbent of the Grand Master's post at the time of the original altarpiece, Winrich von Kniprode, was born near Cologne and it was presumed that he might have engaged an artist from there. A contributory factor to the preference for Northern German areas was that Steinbrecht was a native and even a stalwart patriot of that region. (A significant exception demands attention: the decisive influence of St Elisabeth church of Marburg is unambiguous in several details. Adherence to this model is obviously explained by its belonging to the Teutonic Order, but the relatively frequent employment of craftsmen from there must be accidental.)

The work was chiefly done by local or nearby contractors and artisans, but more exacting jobs requiring special skills such as decorative wall painting, stone carving or stained glass windows with emphasis on medieval character were assigned to artists in most distant German towns, too. (Separate chapters were devoted to the windows and their replacement: Ewa Witkowicz Pałka, in Kościót Najświętszej Marii... 193216, and ead., in Kaplica św. Anny... 145-155.) Credit for the exploration of the prototypes and the craftsmen is due to the authors of the volumes, to the specialists who have been studying the complex for many years and decades busily searching for analogies, and who have also buttressed their findings by scrutinizing the mentioned written material used insufficiently by earlier research: nearly every footnote contains references to items in the archival material kept in the museum.

Unlike earlier, in recent decades a greater stress has been laid on the less glorious later periods of the past. (That also applies to post-WWII German research in general. An impressive example is a carefully built book presenting important sources, too: BoockMAN, Hartmut: Die Marienburg im 19. Jahrhundert, Frankfurt, 1982.) The Polish centuries after the age of the Knights were laden with war havoc and permanent neglect, with a baroque extension here and there. The Prussian, and later the German period was first characterized by total neglect and even the conversion of 
the whole complex into an army depot, followed by romantic but far from authentic rebuilding and finally the late-nineteenth century correct restitution in terms of monument conservation. Voluminous studies enlarge upon the post-war restoration, which can be seen as professionally competent since the founding of the castle museum in 1961. It is thus not concealed that some misperformed operations caused the work to veer in a new direction, and problems concerning the furnishings are also touched on.

Although the size, layout and typographic solutions suggest that the three volumes are strictly coherent, the two editors are also the same, it is still carefully avoided to present them as parts of a series in which case one (logically the first) book would be about the history - at least in a nutshell - of the Order and its most important castle with events indispensable for embedding the studied complex in time. For lack of that, the first chapter of the volume devoted to the Chapel of the Virgin fills this role. Its author Tomasz Torbus only intended to describe the architectural character of the building but in the meantime he narrates so much in connection with it that the reader who wishes to peruse all the studies may use it as a guide for want of a real introduction, at least concerning the beginnings (in Kościót Najświętszej Marii... 9-25; for the other two volumes, one about the St Anne Chapel, and the other about the Priests' Tower: Jakub Adamski, in Kaplica św. Anny... 9-25; Artur Dobry, in Wieża Klesza... 57-65). Torbus guides the reader from the beginning around 1280 to after the mid-fourteenth century, stressing that the scarcity of relevant sources and the difficulty to evaluate the finds cause great uncertainty about nearly every question. Besides, as is often observable with constructions by the Order, they deliberately archaized, which also aggravates dating. For this reason, instead of outlining a straight developmental arc Torbus pits the often contradictory opinions of earlier authors against one another, leaving it to the reader to draw the conclusion. He firmly discards the hypothesis that the upper chapel served the higher ranks and the lower was built for the commoners; this opinion re-occurs in several other studies.

The author of one of the consecutive articles Juliusz Raczkowski (in Kościót Najświętszej Marii... 79-94), who compares the chapel and Sainte-Chapelle in Paris, has quite a different opinion about the influence radiating directly from the latter than Torbus, who disagrees with the direct influence arguing that Sainte-Chapelle had already been consecrated in a then distant past, in 1248 , and it would pay more to study analogies closer in time, in the fourteenth century. Raczkowski, however, insists on his position. In proof of the long-lasting influence of the Paris building he lists several fourteenth- and even fifteenth-century two-storied chapels built in France and points out that similarly to the Paris chapel there were valuable relics in Malbork, too, owing to the activity of the Knights in the Holy Land. Just like in Sainte-Chapelle, the cult of the Cross was an accentuated element. This is evidenced by the scenes of the legend of the Holy Cross in the relief over the entrance to St Anne Chapel; by courtesy of Charles VI, king of France, a splinter from the cross was also kept in the chapel. Another analogy may be that similarly to St Louis on the throne in Sainte-Chapelle who must have felt to be imago dei, the Grand Master always claimed to be rex et sacerdos. The protrusion of the chapel from the block of the castle in both places was inspired by the same intention, the author adds.

Barbara Pospieszna (in Kościót Najświętszej Marii... 95-111) writes about a special feature of Malbork, the $8 \mathrm{~m}$ tall (!) Madonna relief covered with bright-coloured mosaic filling the space of the middle window of the polygonal apse of the upper chapel, its vicissitudes over the centuries and its current renovation. Since the figure was looking eastward, toward the territories of the pagan Prussians still to be pacified, its position exposed it to the gunfire of the approaching front and thus it was totally destroyed in World War II. Later it was reconstructed with extreme difficulties. The required material examinations have shown that the basic elements of this very rare technique outside Italy, the mosaic tesserae, were not brought from Italy as was earlier presumed but are perfectly identical with the ones in Kwidzyn close by. (During a new wave of restoration in the nineteenth century Italian and other German pieces were also added as the conservator of that time required.) The technique must have arrived here in the Middle Ages through the mediation of Prague, although in St Vitus' cathedral the mosaic was created on a flat surface while here a slightly convex artificial stone relief of some plasticity was covered with it.

An extremely long paper (one of the longest in the three books) discusses the architectonic details of the Chapel of the Virgin. Bernard Jesionowski discusses the condition of the walls exhaustively, naturally concentrating on the ornamental carvings as his basic aim is to differentiate at least three phases of construction: that of the first chapel covered with a simple groin 
vault, that of the reconstruction crowned with a stellar vault above the choir (1311-1344) and that of the late nineteenth-century restoration (in Kościót Najświętszej Marii... 153-191). He devotes meticulous care to specify where bricks, stone, artificial stone (ceramic at times for decoration) were used, where and why diverse ornaments were placed, and why some were pulled down or walled up: windows, buttresses, pinnacles, corbels, blind arcades and the like, or just some glyphs. He concentrates on finding out how much of these have remained visible or walled up from the first chapel or the second rebuilt chapel. Noteworthy is the case of the wimpergs adorning the interior: the examinations of the texture of the wall revealed that they were already decorating the first chapel, but when it was enlarged, new ones replaced the initial simple ornaments. The baroque re-styling changed them, but the Steinbrecht-led renovation revived their gothic shape. The ones that can be seen today are from the latter period, although several had to be carved anew after the war.

Jesionowski discusses at length the entrance of the chapel from the cloister-like corridor of the courtyard already designated by medieval sources as the Golden
Gate, for its creation and symbolism have been the source of controversies for a long time (Fig. 1). Taking an interim position, he tries to reconcile views advocating the early origin and those that ascribe it to the second phase, that of the enlargement, by dating some details to the first, some to the later phase. Concerning the hypothesis that the crowned half figure on the apex of the archivolt is the devil, the lord of Hell (Fig. 2), who is eventually subdued by Christ in blessing on the keystone of the vault bay in front of it (Fig. 3), that is, higher than the former figure, the Hungarian reviewer is reminded of the devil head on the peak of the archivolt of the Porta Speciosa of the Benedictine monastery in Pannonhalma built around 1220-1230 (Fig. 4). It cannot be taken for granted that the Malbork figure of a plain face without distorted traits, horns or similar features represents the devil, while in Pannonhalma the freaky face with the gaping mouth guarantees it (Fig. 5).

The editors and authors of the books did not rest content with discussing the conserved and restored architectural, building sculptural details but they probed into what the furnishing and the objects of use of the chapel might have been like. Since from the time of the Knights only a wooden cross and wrecks of stalls

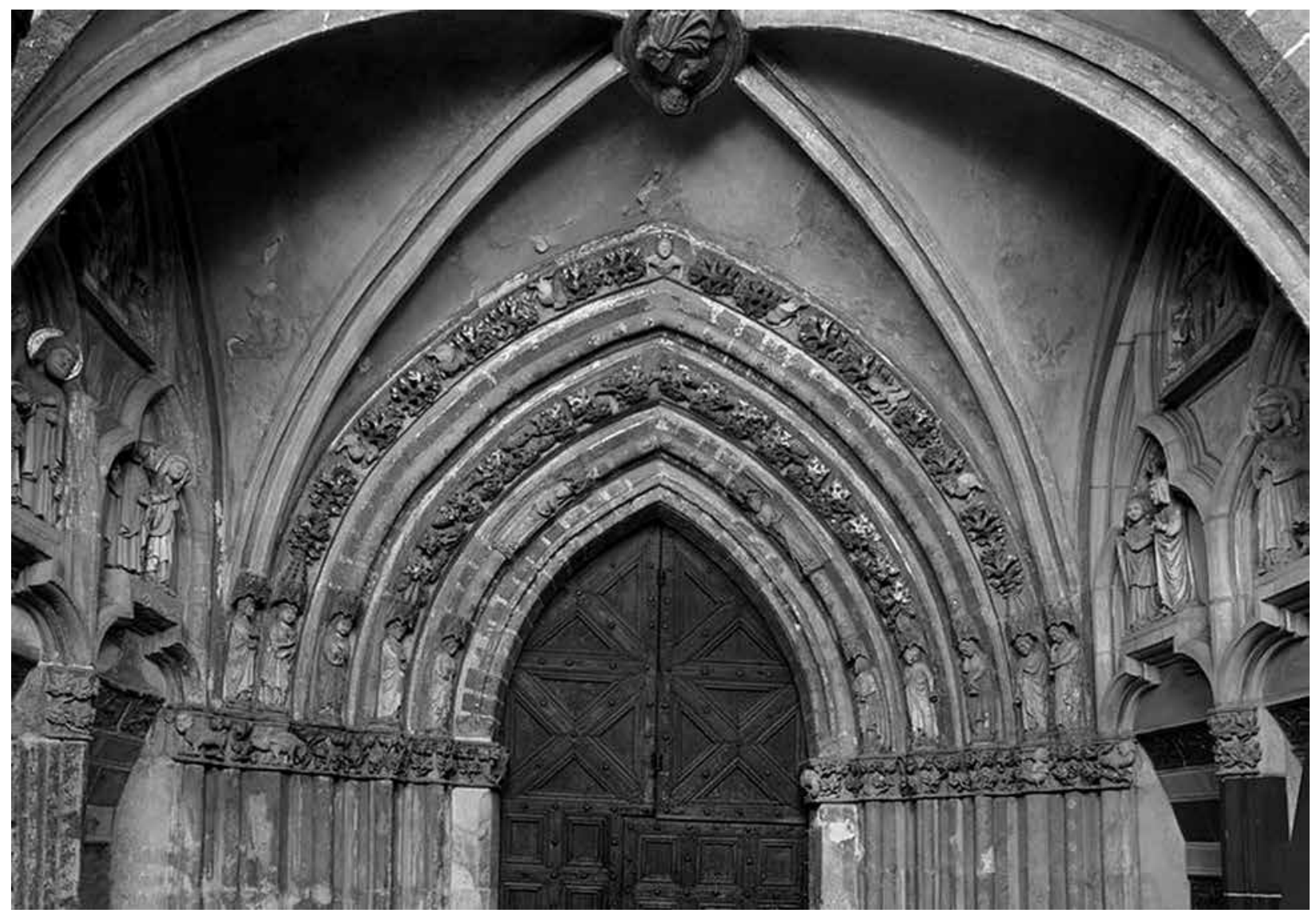

Fig. 1. Malbork, High Castle, Golden Gate, upper part of the bay 


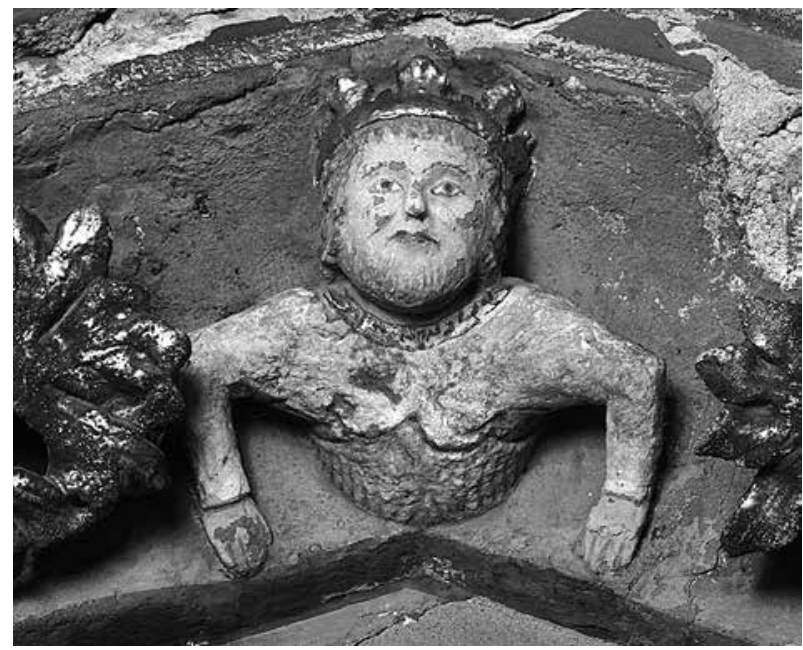

Fig. 2. Malbork, High Castle, Golden Gate, crowned figure, the keystone of the porch

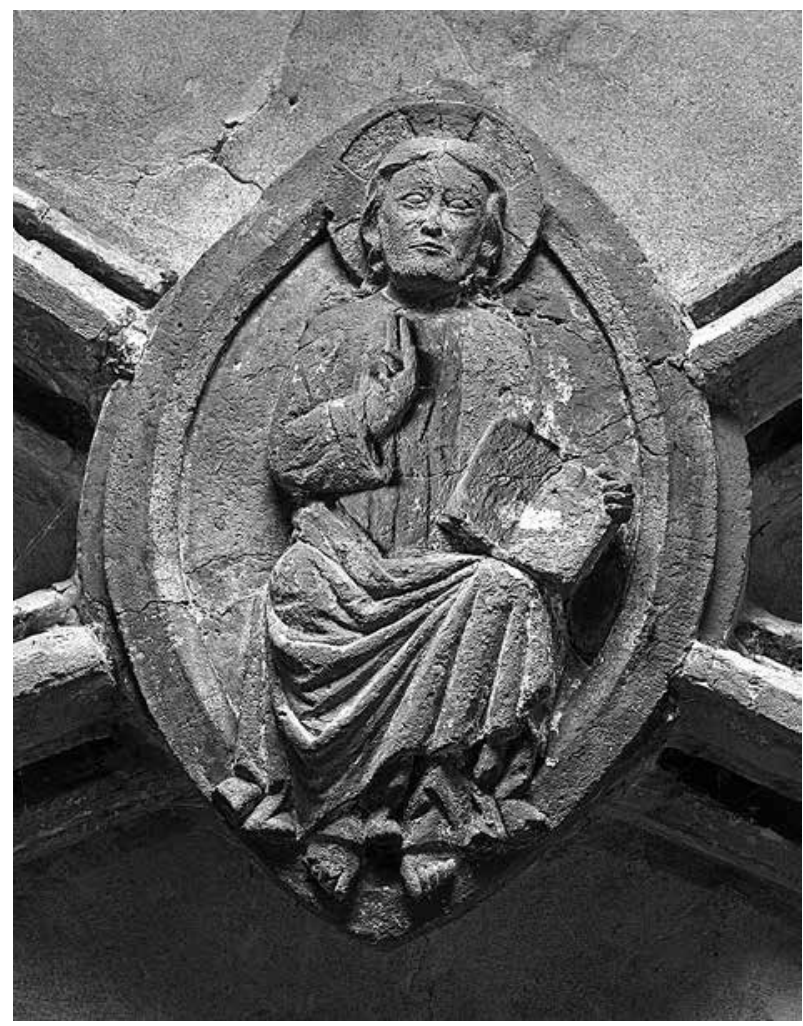

Fig. 3. Malbork, High Castle, Christ in blessing on the keystone of the vault in front of the Golden Gate

survive, Michal F. Wozniak tried to achieve the goal by studying diverse inventories, first of all, medieval ones but used later inventories as well to dig up information about the medieval conditions (in Kościót Najświętszej Marii... 113-125). He can list scores of objects such as relics in ornate reliquaries, pectorals with relics of saints, chalices, processional crosses, paraments, candlesticks, missals and psalters (some in silver cover) and the like which were appropriate for such a pres- tigious chapel. It is noteworthy that there were several sacristies for the storage of different kinds of paraphernalia. At the same time he admits that some fundamental information is still lacking, e.g. where was the oft-mentioned Holy Cross altarpiece, the lectern, and whether the high altar was a winged retable or not. $\mathrm{He}$ also writes about the incomparably less luxurious baroque furnishings and regrets to say that the documents with Steinbrecht's relevant observations perished in the war.

In accord with the importance of the topic two chapters are devoted to the post-World War II reconstruction, which is still not finished. They discuss the events, the legal changes in the management of the institution as well as the repeatedly arising technical and similar problems, and the scholarly conferences related to these problems with the involvement of foreign specialists as well (papers by Mariusz Mierzwiński and Mirosław Jonakowski, in Kościót Najświętszej Marii... 247-266, and 267-285, resp.). Naturally, it does not remain unsaid that UNESCO placed the castle complex on the World Heritage List in 1997.

The first study about St Anne chapel, the undercroft of the Chapel of the Virgin, the subject of the above reviewed first volume (in Kaplica św. Anny... 9-25), written by Jakub Adamski takes a look at several two-storied chapels. Quite a few were built in the territory ruled by the Teutonic Order, including some in which - similarly to Malbork - the undercroft served as the place of burial. The Grand Master who had the upper and lower chapels built and enlarged, Luther von Braunschweig, was a member of the Welf dynasty that provided several Holy Roman emperors in the early Middle Ages, so it is understandable that he had the ambition to create a prestigious burial place, even a mausoleum, for himself and his successors. Though he was eventually buried elsewhere (he died far from his residence, on the way), his successor was buried in 1341, as were all successive grand masters until 1457, when the castle fell into Polish hands. Under a Coronation of Mary scene over one entrance of the chapel the wise and foolish virgins, on the other entrance the Last Judgement are represented, both with eschatological meaning; St Anne was also venerated as the patroness of good death. Sławomir Jóżwiak and Janusz Trupinda emphasize that the churchyard being right next to St Anne Chapel, along its northern wall, is effectively reinforced so that the dead would remain within the community of the Order (in Kaplica św. Anny... 27-36). From written accounts and using 


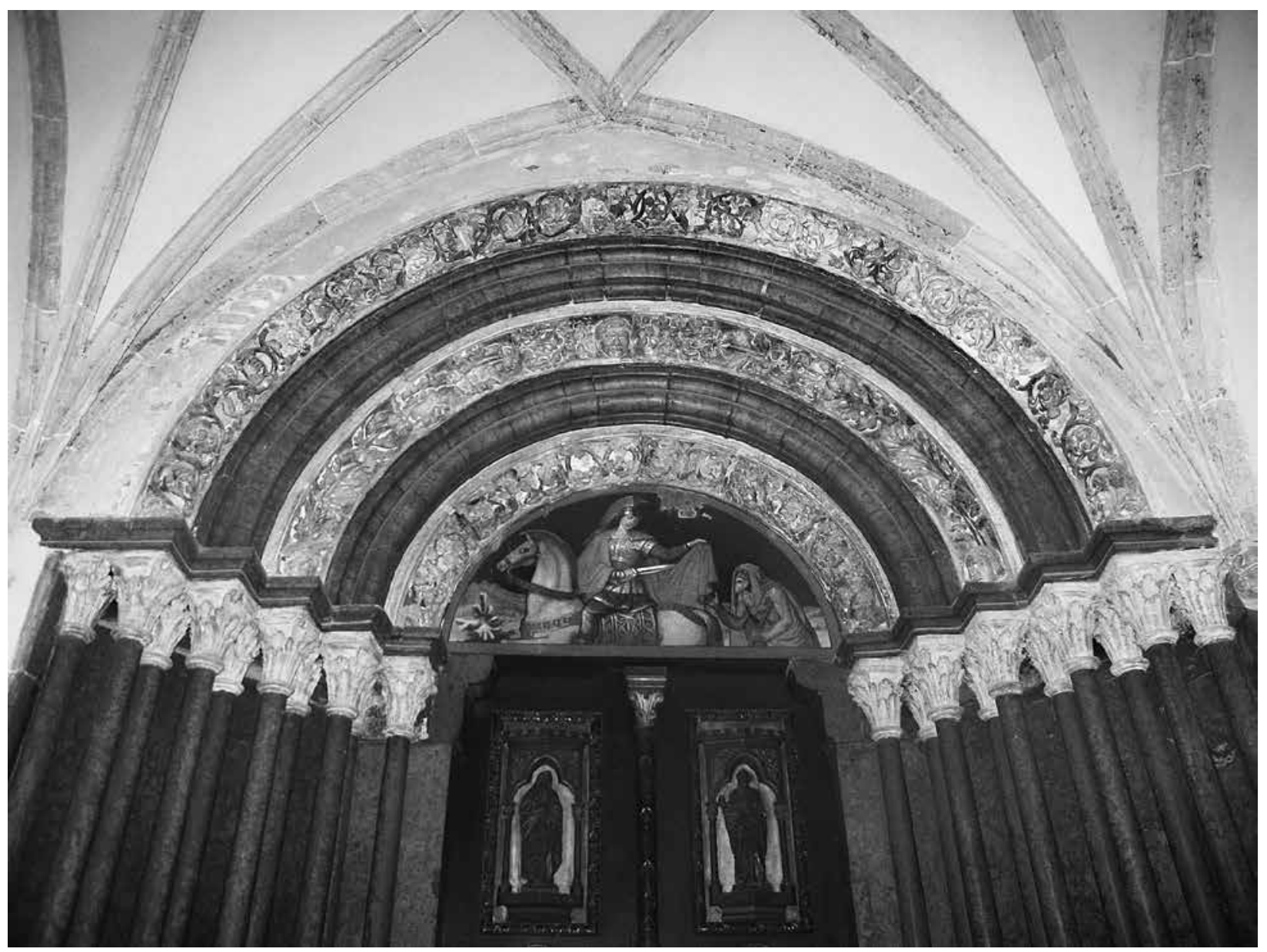

Fig. 4. Pannonhalma, Porta speciosa, upper part of the porch, the diabolic head is in the middle stripe

the funerals of nearby areas as analogies, they tried to uncover some information about the funerary ceremony; they also present the recorded inscriptions of the perished tombstones of some grand masters and finally they stake out the course of further research.

Tadeusz Jurkowlaniec devoted his voluminous study to the tympanum adorned with reliefs above the southern portal of the chapel. He compares at length the views on the dating of the portal - some advocating the early phase of construction, others the phase of reconstruction - and arrives at a compromise: the lower stones - those that determine the location - date from the former period, the higher stones date from the latter (in Kaplica św. Anny... 43-78). As regards the reliefs, he has suspicions about the presumed influence of the Master of Naumburg, not without justification. The author's aim was not so much the analysis of formal questions as the decoding of the easily visible but hard-to-interpret scenes. It is beyond doubt that the events following the discovery of the precious relic in the legend of the Holy Cross were meant to be depicted, but several details remain obscure. He made another attempt at interpreting the scenes in an article shortly afterwards, analysing the sights even more thoroughly and illustrating them with more photos including shots taken of details. It is true of both writings that they have raised several, well-formulated questions, but he has failed to give answers to all of them. (JuRKOwLANIEC, Tadeusz: Historie Krzyża świlttego na portalu kaplicy św. Anny w Malborku, Biuletyn Historii Sztuki 79. 2017. 5-61, with a summary in German) The latter article is followed by a detailed conservationist's report which tried to define the original pigments of the colouring so as to facilitate a future reconstruction (PoKSIŃsKA, Maria: Gotycka polichromia tympanonu portalu poludniowego kaplicy św. Anny na Zamku Wysokim w Malborku. Wyniki badań i interpretacja, Biuletyn Historii Sztuki 79. 2017. 63-69, with an abstract in German). It aptly indicates the difficulties Jurkowlaniec is faced with that in the uppermost strip of the relief showing Emperor Heraclius venerating the Holy Cross, the object of vague outlines in the hands of the figure behind the ruler 


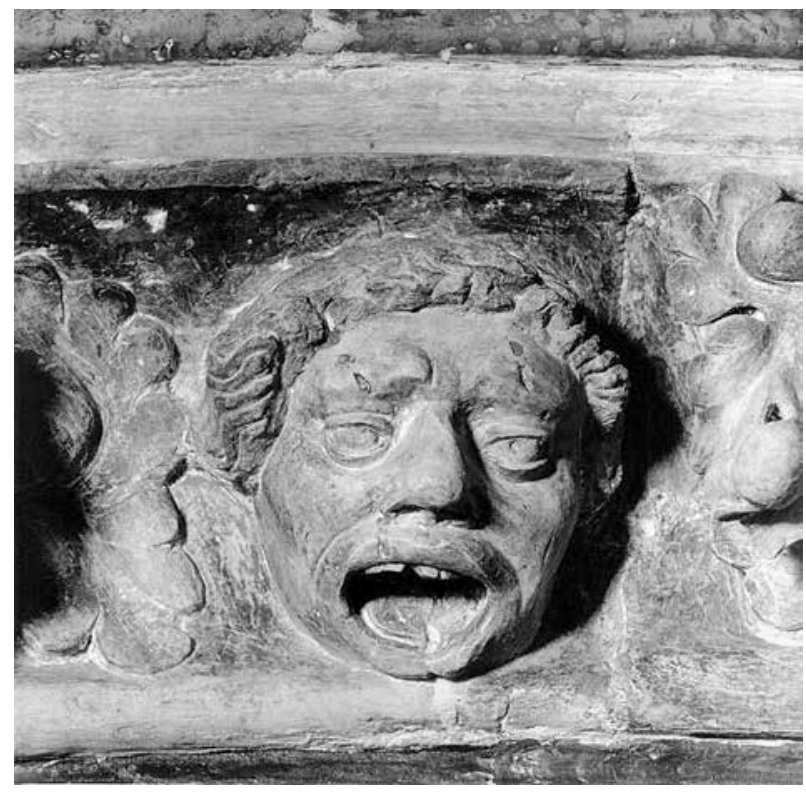

Fig. 5. Pannonhalma, Porta speciosa, the diabolic head, the keystone of the middle stripe

was identified as a cup in the former writing, and as the column used for the flagellation of Christ and worshipped later in Rome as an extremely precious relic of the Passion in the latter article. (Possibly the latter is correct.)

Of course, the interventions of subsequent ages, the later burials have also been examined by the researchers. It clearly shows the wide spectrum of the specialists' interests that results of petrographic investigations are also provided. The sandstone used for the tombstones in the crypt derived from the island of Gotland similarly to the capitals of the wall piers of the upper chapel, while the floor of the chapel came from Livland (partly Lithuania, partly Estonia today); at that time both Gotland and Livland were possessions of the Order.

There are two articles about burials during the stay of the Jesuits in the castle. There were regular excavations in the whole area of the chapel and several corpses were found, some mummified, tossed all over in a mess. It is presumed that the valuables interred with them were stolen. These examinations were carried out with the help of the most up-to-date laser-governed and computer aided technologies (Ks. Wojciech Zawadzki, as well as Magdalena Bury and Andrzej Golembnik, in Kaplica św. Anny... 173-181, and 183-200, resp.).

The third volume of the three reviewed books is the thinnest, adequately for its topic the Priests' Tower and the single-level building next to it, whose significance, and hence degree of decoration, falls short of the Chapel of Mary and the undercroft. Consequently, this is also the least carefully investigated part of the ensemble. The authors of the first paper, Sławomir Jóżwiak and Janusz Trupinda tried to explore how many priests could have lived in the castle: they were probably few, but including the confessor and chancellor of the Grand Master, their influence must have been considerable (in Wieża klesza... 9-13). It is intriguing and typical that they were not subordinated to the bishop of the given diocese but to the Grand Master. Their place of accommodation is sometimes mentioned in accounts or inventories, but it is not sure at all that it was the tower named after them or its surroundings. Wiesław Długokecki's writing informs us that they were usually around twenty and that the later name-give - Bell Ringer - to the smaller building was a dignity rather than an actual job, the incumbent of the post being sometimes in charge of the cellars, or bell founding, or supervising the infirmary (in Wieza klesza... 15-24). There is an article about the Jesuit college erected in place of the two buildings (Janusz Hochleitner, in Wieża klesza... 43-50) and another one about the time when after the suppression of the Order of Jesus the place was at the disposal of the clergy of the small town (Ks. Marek Jodkowski, in Wieża klesza... 51-56). Artur Dobry wrote about the construction of the two existing buildings in the nineteenth century (in Wieża klesza... 57-66). During painstaking excavations a few wall fragments were found but they could not have served as foundations for a tower. In the rooms there was once an exhibition conjuring up the life of yore in and around the castle with furniture, relics of guilds, etc. and frescoes on the walls evoking the medieval atmosphere. All that perished in World War II almost without a trace; after restoration offices and a library were fitted out there.

In sum, it can be concluded that these are three independent books of studies, the editors of which have carefully distributed the topic but have not harmonized the views. It occurs quite often that one can read different views about one and the same phenomenon in different articles, there are no cross-references to inform the reader that something else can be found about the actual topic elsewhere. It would be a great help to the reader to have at least indexes of personal and place names at the end of each volume. The authors have done a thorough job exploring every possible detail, illustrated by a collection of a few dozen old representations of the buildings, which can be battle scenes, portraits with the castle in the background, others were produced expressly in prep- 
aration of a reconstruction or to register a phase of it; more recently the latter were obviously photographs (in Kościót Najświętszej Marii... 27-77, in Kaplica św. Anny... 101-142, in Wieża klesza... 25-40). The authors deserve credit for admitting at several points that unsettled details remain in the history of the buildings even after the most meticulous examination of the walls. That is not surprising, given the many reconstructions of the complex after so many horrible devastations. More or less the same authors have contributed to all three volumes and they are also most frequently mentioned references in the footnotes. That means the best and most sought-after specialists of the theme could be won for the writing of the individual studies. Each study is followed by a short abstract rarely longer than a page in English. It is a great pity that this alone provides some information for readers not understanding Polish.

By way of a conclusion it must be made clear that these three volumes of studies (the number is to increase soon as work on volumes introducing other details of the complex is already underway) are not equivalent with a thorough monograph covering all details which this impressive building complex would deserve. The studies the reader finds in them will, however, provide a highly useful, or we may safely say, indispensable foundation for that opus magnum hopefully to be created sooner or later.

János Végh 